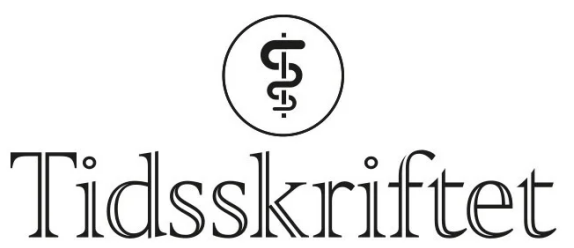

DEN NORSKE LEGEFORENING

\title{
Må vi gjøre alle feil på nytt?
}

DEBATT

\section{MARIT VIDRINGSTAD}

marit.vidringstad@finnmarkssykehuset.no

Marit Vidringstad er varatillitsvalgt for Overlegeforeningen og overlege ved Gynekologisk avdeling, Hammerfest sykehus.

Forfatteren har fylt ut ICMJE-skjemaet og oppgir ingen interessekonflikter.

\section{TORBEN WISBORG}

Torben Wisborg er hovedtillitsvalgt for Overlegeforeningen, Hammerfest sykehus, og professor ved Universitetet i Troms $\emptyset$ - Norges arktiske universitet.

Forfatteren har fylt ut ICMJE-skjemaet og oppgir ingen interessekonflikter.

\section{INGVILD AGLEDAHL}

Ingvild Agledahl er ph.d., Master of Public Health og lege i spesialisering ved Kirurgisk avdeling, Hammerfest sykehus.

Forfatteren har fylt ut ICMJE-skjemaet og oppgir ingen interessekonflikter.

\section{Nye sykehus bygges for små, selv om Sykehusbygg HF skal sikre at erfaringer blir overført.}

Det nye akuttsykehuset som er under bygging i Hammerfest, blir for lite, har for få rom og for få pasientsenger. Grunnsteinen er lagt for et sykehus som blir nytt og moderne, men som ikke er rustet til å ivareta hverken Finnmarks befolkning eller de ansatte på den måten de fortjener.

\section{En visjon som aldri ble noe av}

Sykehusbygg er et helseforetak som ble opprettet i 2014 av de fire regionale helseforetakene. Det primære formålet med Sykehusbygg er å sikre et nasjonalt kompetansemiljø for sykehusplanlegging og -bygging (1).

I begynnelsen av planleggingsprosessen i Hammerfest var prosjektets visjon tydelig, og pasientbehandlingen var i fokus. Også de pårørende skulle ivaretas, med arealer som var egnet for besøk. Etter hvert som planleggingsarbeidet skred fram, har vi opplevd at samarbeidet med Sykehusbygg er blitt vanskeligere. 
Gjennom fem år har fagfolk spilt inn bekymringer. I år rapporterte en arbeidsgruppe med sykehusets øverste ledelse og tillitsvalgte at det mangler hele $79 \operatorname{rom}(\underline{2})$. Dette er rom utenom ordinære pasientrom og poliklinikkrom.

\section{Hammerfest er dessverre ikke alene}

På det nyåpnede Kirkenes sykehus var det opprinnelig planlagt med kun enkeltrom for pasientene. Etter innflytting viser det seg at pasientene ligger to og to på enerom (3). Rommene er så trange at den ytterste sengen må trilles ut først før man kan få ut den innerste sengen. Sykepleierne sitter nærmest oppå hverandre når de journalfører pasientdata, og i mangel på oppholdsrom plasserer pasientene stoler langs korridorene.

«Studenter, sykepleiere og leger kommer til å stå i kø for å kunne bruke arbeidsstasjonene»

Vi frykter korridorpasienter fra første stund etter åpning, som ved Sykehuset $\emptyset$ stfold, Kalnes. Kalnes skulle ifølge helseminister Bent Høie bli et foregangssykehus som Norge kunne lære av, men i den nylig publiserte evalueringen uttaler sykehusets administrerende direktør, Hege Gjessing, at «de ansatte hadde rett hele tiden» (4). I 2017 var det registrert 3 800 korridorpasienter på Kalnes, i 2018 hele 4500 korridorpasienter (5).

\section{Hvor skal de ansatte jobbe?}

Prosjektledelsen for nye Hammerfest sykehus og Sykehusbygg planlegger utstrakt bruk av kontorlandskap for leger og sykepleiere. Dette gjør det vanskelig å opprettholde taushetsplikten. Forskning har også vist at arbeid i kontorlandskap er ineffektivt og øker sykefraværet (므). Ikke minst er det ugunstig med tanke på nødvendige smittevernstiltak ved pandemier. Smitteutbrudd på små lokalsykehus som i Hammerfest medfører en langt større fare for at ordinær drift ikke kan opprettholdes enn ved større sykehus hvor man har flere medarbeidere å dra veksel på. På det meste denne våren var over 10 ooo sykehusansatte i Norge i karantene (7.).

\section{«Det er ikke alltid like lett å reise hjem til Kautokeino etter et dagkirurgisk inngrep på vinteren i Finnmark som det er å kjøre hjem fra Ullevål sykehus til huset sitt i Asker»}

På Universitetet i Troms $\emptyset$ - Norges arktiske universitet, Campus Hammerfest, utdanner man sykepleiere, og gjennom Finnmarksmodellen tar medisinstudentene de to siste årene av utdanningen sin her i Hammerfest. Med den nåværende plassmangelen ved nye Hammerfest sykehus, blir det vanskelig også for studentene å finne arbeidsplasser i det nye bygget. Studenter, sykepleiere og leger kommer til å stå i kø for å kunne bruke arbeidsstasjonene. Dette burde bekymre universitetet.

\section{Uheldige kutt og tåkelegging}

Ett av argumentene for å kutte antall sengeplasser i det nye sykehuset er at flere pasienter skal benytte seg av pasienthotellet. Men pasienthotellkapasiteten er ikke økt i forhold til dagens kapasitet. Det er ikke alltid like lett å reise hjem til for eksempel Mehamn eller 
Kautokeino etter et dagkirurgisk inngrep på vinteren i Finnmark som det er å kjøre hjem fra Ullevål sykehus til huset sitt i Asker. Vi opplever at vi snakker for døve ører når vi forsøker å formidle dette.

I vinter ble $3 / 4$ av det nye sykehusets øverste etasje kuttet. Prosjektleder i Sykehusbygg uttalte til NRK 5 . juli at det ikke er uvanlig at et prosjektert sykehusbygg endrer seg underveis: «Endringen kom på plass for å samle funksjonene» (모). Dette stemmer rett og slett ikke. Endringene ble gjort fordi man så at kostnadsrammen på prosjektet ikke ville dekke det arealbehovet som Sykehusbygg selv opprinnelig hadde estimert at det var behov for.

\section{Hold ikke Finnmarks befolkning for narr}

Kalnes og Kirkenes er skremmende eksempler på hva som skjer når man bygger for lite. Til tross for intensjonen med Sykehusbygg har økonomi stadig blitt siste premissleverandør.

$$
\begin{aligned}
& \text { «Kalnes og Kirkenes er skremmende eksempler på hva som skjer når man } \\
& \text { bygger for lite» }
\end{aligned}
$$

Helse Nords ledelse og styre må nå ta Helse- og omsorgsdepartementet på ordet når de sier: «Kalnes-rapporten bør få følger for planlegging av nye prosjekter og kan være grunnlag for endring i pågående prosjekter» (9.).

På lang sikt er det billigst å bygge et stort nok sykehus med en gang. Utvidelser, nybygg og ombygging er fordyrende. Finnmarks befolkning fortjener et godt akuttsykehus. Det er på høy tid at man lytter til det fagfolk utvetydig har sagt i flere år. Alternativet er en ny, stygg evalueringsrapport - denne gangen over nye Hammerfest sykehus.

\section{LITTERATUR}

1. Sykehusbygg. https://sykehusbygg.no/om-oss Lest 11.8.2020.

2. Styresak 73-2020/7. E-post med vedlegg av 20. mai 2020 fra Torben Wisborg og Marit Vidringstad, tillitsvalgte for Overlegeforeninga - Hammerfest Sykehus ad. Styresak til møtet 27. mai 2020 - Mangel på kliniske kontorer i Nye Hammerfest Sykehus. Bodø: Helse Nord, 2020. https://helsenord.no/Documents/Styret/Styrem\%C3\%B8ter/Styrem\%C3\%B8ter\%202020/20200527/Styresak\%20732020-7\%20E-

post\%2oad.\%2oMangel\%2op\%C3\%A5\%2okliniske\%2okontorer\%2oi\%2oNye\%2oHammerfest\%2osykehus.p df Lest 11.8.2020.

3. Hagerup T. Nye Kirkenes sykehus - nytt, men for lite. Overlegen 2019; 14-5.

4. Gomnæs H, Fange PØ. Direktøren vedgår at mønster-sykehuset er for lite: - De ansatte hadde rett hele tiden. NRK 30.6.2020. https://www.nrk.no/osloogviken/direktoren-vedgar-at-monster-sykehuseter-for-lite_-__de-ansatte-hadde-rett-hele-tiden-1.15073341 Lest 11.8.2020.

5. Braathen F. I fjor lå 4500 pasienter på gangen. Nå må en sengepost flyttes til det gamle sykehuset. https://www.aftenposten.no/norge/i/vmRp7m/i-fjor-laa-450o-pasienter-paa-gangen-naa-maa-ensengepost-flyttes-til-det Lest 11.8.2020.

6. Stranden AL. De som jobber i åpne kontorlandskap er oftere syke. Forskning.no 20.1.2020. https://forskning.no/arbeid-sykdommer/de-som-jobber-i-apne-kontorlandskap-er-oftere-syke/1622039 Lest 11.8.2020.

7. Løkkevik O. FHI mener karantenetiden var for lang. VG 9.5.2020.

https://direkte.vg.no/nyhetsdognet/news/5eb64ab229072doo114bo821 Lest 11.8.2020.

8. Påsche ES. Frykter at nok et sykehus vil bli for trangt. NRK 4.7.2020.

https://www.nrk.no/tromsogfinnmark/frykter-at-nok-et-sykehus-vil-bli-for-trangt-1.15077315 Lest 11.8.2020.

9. NRK. Distriktsnyheter Oslo og Viken 30.6.2020. Sykehuset på Kalnes for lite (oo:29).

https://tv.nrk.no/serie/distriktsnyheter-oslo-og-viken/202006/DKOV98063020/avspiller Lest 11.8.2020. 
Publisert: 26. august 2020. Tidsskr Nor Legeforen. DOI: 10.4045/tidsskr.20.0599

(C) Tidsskrift for Den norske legeforening 2023. Lastet ned fra tidsskriftet.no 26. april 2023. 